\title{
Introducing the Associate Editors for Equity, Diversity, and Inclusion
}

Aligning editorial leadership with core values in Neurology ${ }^{\circ}$

Roy H. Hamilton, MD, MS and Holly E. Hinson, MD, MCR

Neurolog ${ }^{\circledR}$ 2019;93:651-652. doi:10.1212/WNL.0000000000008235

Correspondence

Dr. Hinson

hinson@ohsu.edu

Diversity and equity are 2 of the core values espoused by the American Academy of Neurology (AAN). In upholding these values, the AAN is committed to "building and sustaining an inclusive organization that respects and values the diversity in [its] membership and the communities [it] serve[s]." ${ }^{\prime 1}$ This commitment extends to the Neurology ${ }^{\circledR}$ family of journals. Earlier this year, publication of a humanities piece in Neurology titled "Lucky and the Root Doctor" and the subsequent retraction of the piece brought to light the need for expertise in equity, diversity, and inclusion (EDI) to be housed in the journal itself. To accomplish this goal, 2 new positions were created on the editorial board of Neurology. As the inaugural Associate Editors for EDI, our goal in this editorial is to introduce ourselves to readers and to explain our role, objectives, and approach.

We are both academic neurologists with active research and clinical careers. Both of us have combined those careers with longstanding engagement with issues related to EDI. Dr. Hamilton is a behavioral neurologist and researcher at the University of Pennsylvania in Philadelphia. He is the Assistant Dean for Cultural Affairs and Diversity at the Perelman School of Medicine and the Vice Chair for Inclusion and Diversity in the Department of Neurology at Penn. He is the co-chair of the AAN's Diversity Officers' Working Group, and a veteran contributor to the pages of Neurology and other academic journals on issues related to EDI. Dr. Hinson is a neurointensivist and clinical researcher at Oregon Health and Science University in Portland. Her expertise in EDI issues stems from her background in health care disparities research and lived experience. Her group recently published a survey on AAN members' preparedness to care for sexual and gender minorities. In addition, she is the founding member and current chair of the AAN's lesbian, gay, bisexual, transgender, queer, questioning, and intersex section.

The purpose of our editorial work will be to assist authors in ensuring the content is respectful and affirming to minority populations. These minority communities include racial and ethnic minorities, and sexual and gender minorities, but could include other minority groups such as those with disabilities. We will offer suggestions, when appropriate, for best practices when describing minority populations. (One such example might be for an author not to use sex and gender interchangeably.) Importantly, our role is not to serve as content censors. Articles will not be rejected if we do not agree with the politics or views expressed in a piece. We are here to offer guidance on best practices, but in the end, the final content will be the responsibility of the authors. This approach reflects the position of the Editor-In-Chief, Dr. Gross, and the editorial staff that the journal should have a forward-looking approach to EDI issues rather than a reactive one. That approach is multipronged. One aspect is the availability of EDI review of manuscripts that are being considered for publication. Another is to provide cultural competency training to the editorial teams of the Neurology family of journals to raise awareness of topics such as implicit bias. A third is to consider scholarly content that addresses EDI. These are important steps to holistically improve the quality and the generalizability of the articles the journal publishes. These efforts represent the beginning of a process that will expand in the

From the Department of Neurology (R.H.H.), Perelman School of Medicine, University of Pennsylvania, Philadelphia; and Departments of Neurology and Emergency Medicine (H.E.H.), Oregon Health \& Science University, Portland.

Go to Neurology.org/N for full disclosures. Funding information and disclosures deemed relevant by the authors, if any, are provided at the end of the article. 
future (for example, helping to develop strategies to assure that the journal's editorial board is broadly representative).

With respect to our contribution to the manuscript review process specifically, our reviews will primarily pertain to research involving human participants. If an outcome variable or key covariate in the analysis of a research study is a sociodemographic variable such as gender, race, sexual orientation, gender identity, or ethnicity, the article may be appropriate for EDI review, although not necessarily. Global or population health articles will not always require our review. We are also available should any Associate Editor ask for assistance. Our process and time course are similar to the existing biostatistical review, and importantly will not slow down the review timeline. Feedback will be provided to authors in conjunction with the conventional review process.

By enhancing the context and nuance with which the Neurology family of journals approaches sometimes challenging topics related to EDI, we are committed to strengthening the overall academic rigor of these publications and to reaffirming the core values that make our professional organization so valuable to its members and to the patients we serve. We are grateful to have been asked to contribute valuably to EDI efforts in the field of neurology, and we look forward to interacting with editors, authors, and readers of these outstanding journals.

\section{Study funding}

There is no funding associated with this editorial.

\section{Disclosure}

The authors report no disclosures. Go to Neurology.org/N for full disclosures.

\section{Publication history}

Received by Neurology August 2, 2019. Accepted in final form August 8, 2019.

\section{Reference}

1. AAN vision, Mission, Goals and Values [online]. Accessed at: https://www.aan.com/ AAN-Resources/Details/about-the-aan/mission-vision/. Accessed August 28, 2019. 


\section{Neurology}

\section{Introducing the Associate Editors for Equity, Diversity, and Inclusion: Aligning editorial leadership with core values in Neurology ${ }^{\circledR}$ \\ Roy H. Hamilton and Holly E. Hinson}

Neurology 2019;93;651-652 Published Online before print September 11, 2019

DOI 10.1212/WNL.0000000000008235

This information is current as of September 11, 2019

Updated Information \&

Services

Citations

Subspecialty Collections

Permissions \& Licensing

Reprints including high resolution figures, can be found at: http://n.neurology.org/content/93/15/651.full

This article has been cited by 1 HighWire-hosted articles: http://n.neurology.org/content/93/15/651.full\#\#otherarticles

This article, along with others on similar topics, appears in the following collection(s):

All Practice Management

http://n.neurology.org/cgi/collection/all_practice_management Inclusion, Diversity, Equity, Anti-racism, and Social Justice (IDEAS)

http://n.neurology.org/cgi/collection/all_equity_diversity_and_inclusio n

Information about reproducing this article in parts (figures,tables) or in its entirety can be found online at:

http://www.neurology.org/about/about_the_journal\#permissions

Information about ordering reprints can be found online:

http://n.neurology.org/subscribers/advertise

Neurology ${ }^{\circledR}$ is the official journal of the American Academy of Neurology. Published continuously since 1951, it is now a weekly with 48 issues per year. Copyright () 2019 American Academy of Neurology. All rights reserved. Print ISSN: 0028-3878. Online ISSN: 1526-632X.

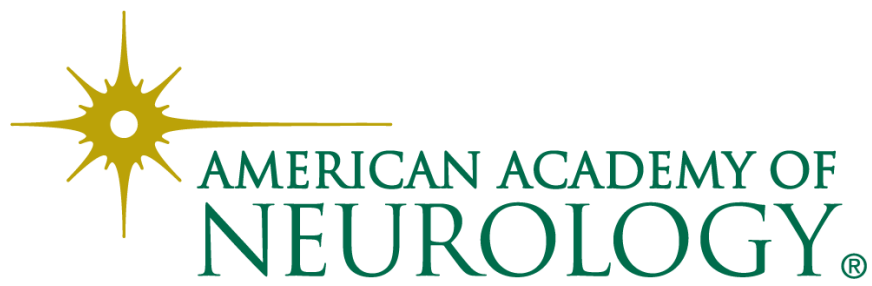

